\title{
Dialogue
}

The Pacific Islands and the Globalization Agenda

STEWART FIRTH

The Contemporary Pacific, Volume 12, Number 1, Spring 2000, 177-192

(C) 2000 by University of Hawai 'i Press 


\section{The Pacific Islands and the \\ Globalization Agenda}

Stewart Firth

\section{G} Ilobalization is now a central theme in the affairs of the Pacific Islands, and Pacific Islands governments are caught up in the rhetoric, the ideology, and the economic policies of globalization. Policymakers in governments and regional organizations pepper their conversations with phrases drawn from that branch of politics called economics. These include "achieving effective private-public sector partnerships," "improving the attractiveness of the foreign investment regime," "facilitating investment transparency," "adopting free and open trade amongst our Island countries," "reducing public sector subsidies," "promoting integration into the world economy," "enabling public enterprises to operate on commercial principles," "providing a policy environment to encourage commercial activity," and "encouraging the development of the private sector so that it assumes a leading role as the primary engine of growth."

Where did this language and these ideas come from? To answer these questions, it is first necessary to define globalization, a term with many meanings in the fin-de-siècle conversation about the state of the world, signifying everything from the expansion of Europe since Columbus to the emergence of a global, Americanized consumer culture. These wider historical and cultural definitions are too broad to be useful for my argument, which focuses on the economic dimensions of globalization. So I follow two economists, Paul Bairoch and Richard Kozul-Wright, in calling globalization a "process in which the production and financial structures of countries are becoming interlinked by an increasing number of cross-border transactions to create an international division of labor in which national wealth comes, increasingly, to depend on economic agents

The Contemporary Pacific, Volume I2, Number I, Spring 2000, I78-I92

(C) 2000 by University of Hawai'i Press 
in other countries" (1996, 3). Globalization is characterized by huge increases in flows of capital across the world, rapid growth in trade, the emergence of new kinds of trade in services, a technological revolution in communications that makes the globe itself the site of operations for major companies, and the growing influence almost everywhere of market forces.

People agree that these developments should be called globalization, but they disagree about whether globalization is new, to what extent it undermines the power of states, and how governments should respond. I consider these issues one by one.

First, globalization is sometimes thought to be without precedent. In some respects-above all in the speed and volume of global information flows-it has no parallel in history. Yet in other respects the globalization of the present era can be seen as a return to an earlier period of globalization that began in the I870s and ended in I9I4. As in the present, new technologies of transport and communications were combining with capitalism to spread markets worldwide. The parallels with the computerization of the late twentieth century were the railways, telegraphs, and underwater cables of the late nineteenth, linking the world together for the first time. At that time, as now, capital moved freely about the globe in search of the highest returns, and governments did not restrict its flow. Multinational corporations were engaged in direct foreign investment on a scale, which, at more than nine percent of global output in I9I3, was comparable with such investment at the end of the twentieth century. Britain, the world's greatest exporter of goods, services, and capital, was a free-trade country and had imposed free trade on many parts of the colonial world. By this interpretation of global economic history, a first era of globalization was interrupted by two world wars, a depression, and a quarter century of government controls and Keynesian regulation from which the world began to emerge only in the r970s.

Second, experts disagree about whether globalization undermines the power of states. Some say globalization is rapidly rendering national borders irrelevant to economic activity, removing the power of governments over national economies, and ushering in an era when states will cease to matter in a borderless world. Some even say the time is approaching when hundreds of millions of people in a global cyber-economy will interact economically on the Internet, beyond the reach of government regulations and taxes. Others say the world economy is no more integrated now 
than it was at the end of the nineteenth century, and that state power remains largely unaffected.

The more convincing view lies between these extremes. Globalization has shifted the balance of power between markets and states in markets' favor and between capital and labor in capital's favor. Globalization has broadened the scope of market power while reducing that of government power; since capital can move from one country to another more easily than labor, capital exercises leverage over the terms on which labor is offered, such as wages and working conditions. Globalization is changing the modern state in fundamental ways. Countries now compete more aggressively for shares of the world market. Governments assess policies by international standards. The highest efficiency in one location on the globe becomes the "international best practice" that all other states seek to emulate for the sake of their own export industries. If one country's corporate taxes are higher than another's, then the higher taxes will be reduced in order to discourage firms from moving offshore; wages in one country adjust to competition from labor elsewhere; and governments are transmitting international forces rather than sheltering people from them.

The real question is not whether globalization influences governments but how much. Governments often claim that globalization leaves them with no option but to sell off government-owned assets and reduce the role of the state in the economy. Much as they might wish to retain assets in government ownership, spend more on education, protect employment, and so on, they cannot-they say-because otherwise their country would lose international competitiveness and offend the financial markets whose confidence is vital to national prosperity. While this claim is true, governments often want to privatize and deregulate anyway, and find it convenient to claim that globalization forces their hand.

The fundamental reason behind the urge to privatize and deregulateindeed behind globalization itself-is the displacement since the I970s of one version of economic theory called Keynesianism, championed by economists such as J K Galbraith, with another called economic rationalism or neoliberalism, which is now the set of economic ideas behind the policymaking of most governments and of leading international financial institutions such as the International Monetary Fund, the World Bank, and the Asian Development Bank. There exists an ideology of globalization, an interpretation of how the world works and what should therefore be done. The ideology of globalization combines the notion of a lost 
golden age, said to exist before governments began regulating economies, with the promise of a future utopia, still out of reach but attainable if the right path is taken. Difficulties along the way-high unemployment, job insecurity, financial crises, and so on-must be endured for the sake of getting to the final goal. Ideologies do not come from nowhere; they coincide with interests, in this case with those of the American and European multinational banks, pension funds, and hedge funds that benefit from global economic arrangements characterized by free movement of capital, small government, low taxes, constrained labor, low wages, and a diminished welfare state. Conspiracy theories are not needed to explain this coincidence of ideology and interest. It is to be expected.

\section{Globalization and the Pacific Islands}

I now return to the idea of two periods of globalization and examine the first one, which lasted roughly from the I850s to I9I4. This first period of globalization was when Pacific Island economies began to be integrated into the global economy, as the buccaneers of global capitalism arrived on their shores. The newcomers were sandalwood traders, copra traders, planters, labor recruiters, guano miners, settlers, themselves driven by the uprooting forces of the emerging global economic system to seek a living beyond the legal systems of their own countries. As they collided with the people who lived in the Pacific and had their own ways of doing thingsnot always to the newcomers' liking-they appealed to home governments for protection from the lawlessness of the frontier they themselves had created. They wanted land claims approved, laborers controlled, debts paid, and livelihoods secured. They wanted the law they knew, the one that protected property, constrained labor, and made profits possible.

The home governments of these buccaneers did not rush to raise the flag so they could rule on the settlers' behalf and extend the domain of Western-style capitalist development. The historical process was more complicated. Some home governments, especially that of Great Britain, had to be persuaded that establishing colonies was worth the trouble. In certain cases-above all that of Britain in Fiji, but also Germany in Samoa-the early colonial administrators were determined to discourage white settlers, to disallow land claims, to preserve tradition, and to protect Pacific peoples from rapid and uncontrolled modernization. Only in one caseFrance in New Caledonia-did a European power succeed in creating a 
white settler colony in the tropical Pacific. A French company at one stage claimed to have purchased half of Vanuatu, but did not attract enough settlers to transform that claim into effective white settler occupation.

The dark vision of many Europeans of the time was therefore unfulfilled. That vision was that the Pacific peoples were doomed to extinction and the Europeans were destined to take their place. History, they thought, would quietly and inevitably perform a kind of ethnic cleansing, leaving the islands free for European occupation. Charles Woodford, the British resident commissioner in the Solomons, wrote as much to the governor of Fiji in I909. Woodford was the man in charge, the equivalent of a colonial governor, and in his words, "The whole population of the British Solomons ... will disappear. . . My opinion is that nothing in the way of the most paternal legislation or fostering care, carried out at any expense whatever can prevent the eventual extinction of the Melanesian race in the Pacific. This I look upon as a fundamental fact and as certain as the rising and setting of the sun" (Bennett I987, I46-I47). As historian of the Solomon Islands Judith Bennett commented, "the resident commissioner reasoned that since all the islands would one day be totally depopulated it would be in the best interests of the government and the future of the Solomons to buy up the land" (1987, I47).

The overall effect of the coming of the colonial powers to the Pacific was nevertheless to incorporate island territories into the global economy on terms that suited the colonizing powers. In the age of the first globalization, no one for a moment thought that the imperial governments in London or Paris or Berlin should pay the costs of governing tropical dependencies. Colonial governments were expected to raise the money for that, and the only way of doing it was to move colonies as fast as possible toward the cash economy, preferably by means of foreign investment in the tropical resources valued by the Western world. The spur to rapid Western-style economic development was, as much as anything, the burning need by colonial governments to have a modern tax base.

\section{The First Globalization}

Patterns of development differed from territory to territory, and colonial powers protected native interests more in some places than in others, but across the region the first globalization rapidly shaped colonial economies into forms that were to last for much of the twentieth century. 
Sugar transformed Hawai'i. Sugar, sold at great profit to the United States after I875, made Hawai'i so valuable to American planters that they overthrew the independent Hawaiian government in 1893 and then took Hawai'i into the union as a territory five years later. Queen Lili'uokalani, the deposed queen, wrote, "It had not entered our hearts to believe that these friends and allies from the United States . . . would ever ... seize our nation by the throat, and pass it over to an alien power. . . An alien element composed of men of energy and determination control all the resources of Honolulu and will employ them tirelessly to secure their ends" (Dougherty I996, I7I). Not only that, the men of energy and determination brought scores of thousands of people from other parts of the world as indentured laborers for the sugar plantations-from Japan, China, Portugal, Korea, and the Philippines especially-changing the face of Hawai'i forever and consigning the Hawaiians to minority status in their own land.

Sugar transformed Fiji too, and in ways well known. Less well known, however, is just how successful Fiji was as a sugar exporter, with the value of exports per head of population not far behind that of countries such as Australia and New Zealand by I9I3, and with a favorable balance of trade for 59 of the 65 years between I 875 and I939. The trouble is that Fiji's sugar success was not translated into markedly higher standards of living for its people. According to Bruce Knapman, the distribution of proceeds from Fiji's sugar exports in the early twentieth century was like this: the Colonial Sugar Refining Company got 62 percent, the white planters 36 percent, and the Indian laborers just 2 percent (I985, 66-83). And most of the company's 62 percent ended up in Australia and New Zealand, not in Fiji. The copra trade worked in much the same way. Like all tropical colonies during the first globalization, Fiji was a low-wage colony. For a couple of decades between the world wars, sugar also transformed the Northern Mariana Islands, which had a sugar industry almost as big as Fiji's by the end of the I930s. But this was a temporary transformation, reversed when the victorious Americans drove out the Japanese in World War II.

In most other places copra was king. The early European colonists in the Pacific tried to grow all sorts of things-tobacco, rubber, coffee, vanilla, cacao-hoping they would become rich by selling to a global market. But plant diseases and a shortage of labor defeated them, and in the end, with a few exceptions such as rubber in Papua and coffee in New 
Caledonia, only one thing really worked-copra. Nowadays, coconut plantations are not regarded as the leading edge of foreign investment, but that is what they were in the I 880 os and I 890 os. If their coconut palms were bearing by 1900 , the planters were in luck. As the world price of copra increased between I900 and I9I4, profits on copra plantations skyrocketed. The big German plantation company in Samoa was paying dividends worth 36 percent a year in the years before World War I. Copra was not only king, it was money. Then there were the minerals that could be dug up and taken away-phosphate, gold, and nickel. Phosphate produced the greatest profits of all for the shareholders of the companies that mined it in Nauru, Banaba, Angaur in Palau, and Makatea in French Polynesia.

What, then, did the Pacific Islands look like during this first globalization? Like most of the rest of the tropical world, the easily accessible parts of the islands underwent a modernizing revolution in the half century before I9I4. Globalization, when combined with colonial rule, meant incorporation into the global economy on terms that suited the interests of the colonial powers, whether the main export was Nauru phosphate, Fiji sugar, Solomons copra, or Papua gold. The modernizing revolution was not, however, one that propelled the Pacific Islands region to Western standards of living, except possibly in a few places such as the Cook Islands.

The place of the tropical world in the first globalization was subordinate to the temperate and developed world. Wages were low, employers used every conceivable device to keep them that way, and colonial governments stood firmly behind employers. The Pacific village, and the labor of the village women who remained behind while their men were away, served as a hidden subsidy for a universal low-wage system. A great, transforming upheaval took place in many parts of the Pacific Islands in the half century before I9I4. Young men in the coastal villages of Papua, New Guinea, the Solomons, and Vanuatu left in their tens of thousands to spend two, three, or five years under contract on plantations elsewhere in the region or in Queensland. Some sixty thousand people came to Fiji from the Indian subcontinent. A new kind of society arose everywhere in the region-a colonial society-in which new political alliances replaced old ones and a new caste system was superimposed on older, traditional forms of government and means of status acquisition, sometimes through alliances with existing chiefly classes as in Fiji, sometimes not. 


\section{The Second Globalization}

In the Pacific, the current globalization dates from, say, the early I970s and is having a profound impact. The first question one might ask is where the pressure is coming from to follow the globalization agenda. The answer is that all the significant sources of advice for economic policymakers in the Pacific Islands now say the same thing. They are aid donors, international financial institutions, banks, and investors, and they agree that salvation for the economies of the region lies in opening themselves up to international forces and becoming truly competitive.

Australia, for example, now prescribes the globalization agenda as a cure for the ills of the Pacific Islands. A 1993 report by the National Centre for Development Studies in Canberra, Pacific 2010, summarized the new orthodoxy in Australian thinking about the region. Its authors predicted that unless island governments changed course, their people would face a nightmare of rising populations, falling living standards, decaying schools, urban squalor, and unemployment. According to Australia, Pacific Island countries should reduce their public sectors, cut tariffs, encourage private enterprise, and allow maximum freedom to foreign investors in order to become more competitive in a globalizing economy. Australia embraced this new hard-headed approach to its Pacific aid policy in I994, when Minister for Pacific Island Affairs Gordon Bilney broadcast a speech to island capitals, declaring that he could see "no realistic alternative to competition and the pursuit of comparative advantage, no matter how daunting these concepts may appear." There is a new conditionality in Australian aid, which means using aid as a carrot and stick to ensure Pacific Island governments reduce the size of their civil services, privatize, encourage foreign investment, and so on.

The European Union makes the same point. In its 1996 Green Paper on relations with the African, Caribbean and Pacific nations, the European Union called for "structural adjustment," "integration into the global trading system," and "good governance."

The region is listening. As the Cook Islands Prime Minister Sir Geoffrey Henry told the Pohnpei meeting of the South Pacific Forum in I998, economic reform issues had risen to the top of the international agenda, "stimulated by fundamental changes in the international economic environment." The I998 Forum Economic Ministers Meeting (FEMM) measured their success against the key criteria enunciated by the three inter- 
national economic institutions that now have the greatest influence on economies in the Asia-Pacific - the World Trade Organization (wTO), the International Monetary Fund (IMF), and the Asia-Pacific Economic Cooperation group (APEC). The issues addressed by FEMM 2 were "open, liberal and transparent investment policies," "strategies for enhancing competitiveness," "rationalising and progressively reducing tariffs," multilateral trade liberalization, and almost as an afterthought, the "reform impact," that is, the effect of policy changes on the people of Pacific Island countries. The theme of the 1998 South Pacific Forum meeting in Pohnpei"From Reform to Growth: The Private Sector and Investment as the Keys to Prosperity" - captured the spirit of the times. The Forum "noted the importance of the private sector and investment as the keys to economic growth and agreed that efforts should be made to ensure macro economic stability by improving fiscal discipline, further progressing public sector reforms and broadening the tax base" (Forum Secretariat I998, 56). Translated, this means that Forum island governments will give business open slather, spend less, cut the numbers of civil servants, and move more of the tax burden from companies to individuals.

The Pacific Islands had no choice whether or not to accept the first globalization, and they have no choice this time either. Pacific Island governments in the late I990s have no alternative but to embrace policies of economic liberalization. The international pressures are too great to do otherwise, and the capacity of international financial institutions to compel obedience too large. Yet at the same time they should fear the full effects of open global competition and understand the implications for the people of the region of what is happening.

\section{Characteristics of Globalization}

The three major characteristics of globalization that might affect the Pacific Islands are the move toward free trade, the technological revolution in communication, and the freedom of capital movement around the world. I discuss each of these in turn.

\section{Free Trade}

The world is moving toward free trade in goods and services. Countries are liberalizing trade by lowering and removing tariffs, quotas, and subsidies. Special trading arrangements are now regarded as antiquated. One example is the Lomé Convention between the European Union and 
African, Caribbean, and Pacific states (ACP), which include Fiji, Kiribati, Papua New Guinea, Samoa, Solomon Islands, Tonga, Tuvalu, and Vanuatu. These Pacific states have for years benefited from trade preferences under the Lomé Convention that give their agricultural exports preferential access to the European market. Fiji in particular has depended heavily on the high price for its sugar paid under the Lomé arrangements, a price that has sustained an entire social system of small-farm sugar production by mostly Indo-Fijian tenant farmers. Both Fiji and the Solomons have benefited from Lomé arrangements that permit canned tuna to enter the European Union duty free, while canned tuna from elsewhere pays a tariff.

The Fourth Lomé Convention, covering aid and trade to former European colonial dependencies in Africa, the Caribbean, and the Pacific, expires in 2000 , to be replaced by arrangements that are yet to be negotiated but will not offer trade protection of the old kind. Lomé IV could not be succeeded by something similar, because its protective provisions run counter to wTO rules about international trade. In any case, the global movement toward free trade renders special trade concessions less special.

Much is at stake in this transition from Lomé IV to what is called the Successor Agreement. The Pacific ACP states met in Suva last year and fashioned a joint negotiating position, which ACP ministers then took to the ACP-EU talks in Brussels in September and October, the start of a diplomatic process that, as Sir Geoffrey Henry said, would "no doubt prove long and arduous." Ministers emphasized the region's economic reform credentials and hoped that, post-Lomé, their small and isolated countries would not be left to survive entirely without protection in an increasingly free-trade world. The negotiations are continuing.

No one imagines that Lomé will simply be restored in its present form. The special protection of Fiji's sugar exports is coming to an end, and with it perhaps the way in which sugar has traditionally been grown in Fiji. Once that protection is gone, the marginal farms will be gone, more and more people from the sugar belt will move to the towns, and Fiji will be more urbanized than ever. By one estimate, the removal of Lomé preferences would reduce the average cane farmer's net income from $\mathrm{F} \$ 4,300$ to $\mathrm{F} \$ \mathrm{I} 65$. It is even conceivable that the whole concept of small-farm sugar production might become so uneconomic in the long run that it has to be abandoned, with a return to the original system of producing sugar on large mechanized estates. That now happens, I understand, in Mauritius, which is sometimes held up as a model for Fiji to follow. The social 
and even political consequences for Fiji might well be profound, just as they might be if the losses of the tuna cannery in Ovalau grow and the Pacific Fishing Company's whole operation has to be closed down, throwing hundreds of mainly women workers out of a job. I give these as examples of my general proposition, which is that the second globalization could well prove to be as transformative for the Pacific Islands as the first.

\section{The Technological Revolution and Electronic Commerce}

The flow of electronic information across national borders is growing exponentially year by year. On the face of things, the growth of electronic commerce and the Internet might appear to offer countries like Fiji an opportunity, because they finally abolish the constraint that experts have always complained about in this part of the world. They abolish distance and render it irrelevant. If Fiji had a highly educated workforce in the area of computer software, it is possible that Fiji-and other Pacific countries for that matter-could develop export industries in computer expertise, with the exports going silently into space to satellites and then down to computer companies in Silicon Valley in California. The trouble is that the pace of sophistication in the computer industry is so fast that specialization in computer skills would be difficult for island countries to develop—not impossible, but difficult.

\section{The Mobility of Capital}

A third characteristic of the modern global economy is the freedom of capital movement. Massive amounts of money are being invested and withdrawn from investment across national borders as global financial markets decide where capital should and should not go. The essence of the Bretton Woods system of rules for the operation of the global economy after World War II, conceived in the wake of the Great Depression, was to liberalize international trade while regulating international capital movements. The essence of the global economic order since the I970s has been to liberalize trade further and to deregulate capital movements altogether. The result is a dynamic, yet inherently unstable and volatile global economy, in which countries that fall out of favor with the international financial markets can be plunged into sudden currency devaluations, widespread bankruptcy, unemployment, and-as is happening in Indonesia-social unrest, religious hatred, and violence.

Freedom of capital movement allows for speculative capital flows that 
follow a logic with little relevance to a country's real economic prospects. The cost is borne by bankrupt businesses, unemployed workers, drastically restructured economies, and destabilized governments. Things were no different in the first era of globalization. Speculative flows of capital into Argentina in the late I 88 os, for example, fueled a real estate boom that ended in a crash, recession, widespread unemployment, and the sale of many Argentine businesses cheaply to foreign investors. Then, as now, financial collapses transmitted themselves rapidly from one country in a region to other parts of that region, and eventually to the entire global economy. There are striking parallels with the 1997 Thailand crash, which spread quickly to other East Asian economies and beyond.

Almost us $\$$ Ioo billion flowed into Thailand, Indonesia, Malaysia, the Philippines and South Korea in I996, up from us\$4I billion in I994. Having fueled a boom in these countries, the banks and other capital holders turned a massive inflow of private capital into an outflow of US \$ 12 billion in I997, as investors stumbled over each other in the rush to get their money out. Banks competed with each other to lend money, and investment funds competed to buy shares for as long as the market mood dictated that East Asia was in favor. Competition among the lenders made borrowing cheap. Money was easy to get, and East Asian businesses made unwise decisions, fueling a boom in asset prices that could not be sustained.

The psychology of capital markets is different from that of markets in goods and services. Players in capital markets are given to panics and manias. Investors praise national economic performance one day and denounce it the next. The abrupt reversal in the way the international financial markets interpreted prospects for East Asian economies-moving from excessive optimism at the beginning of I997 to extreme pessimism by 1998 - owed more to the irrational psychology of the capital market than to economic reality. Just as a herd mentality distorts investors' judgments as a boom builds, so it fosters panic during a crash. What some investors do, irrespective of the merits of the case, becomes the decisive consideration for other investors on the way up and on the way down. While the behavior of individual market players is rational from their point of view, the behavior of all players acting together is not. As the contagion spreads, the market's loss of confidence in a national economy becomes a self-fulfilling prophecy as the currency is devalued, interest rates rise, and businesses lose the capacity to repay foreign debt. 
Classical economics of the kind that has inspired economic rationalism makes little allowance for this irrational, psychological side of market behavior.

In the East Asian case, almost all the effects of the sudden withdrawal of capital were negative from the point of view of governments and people in the region. As the demand for national currencies disappeared, governments were forced to push up interest rates, mostly to levels that caused widespread bankruptcies. Then came the fire sale of East Asian companies, now desperate for cash and willing to sell to foreign multinationals. The American firms DuPont, Coca-Cola, Eastman Kodak, General Motors, and Procter \& Gamble were among the multinationals that bought cheaply into the region in I998. The immediate effect of the crisis, then, was to compel a number of East Asian governments to surrender policymaking autonomy, accept the rules of the globalized economy, loosen controls on foreign ownership, permit an Americanization of parts of their economies, and submit to the conditions demanded by the International Monetary Fund in return for loans.

The small currencies of the Pacific Islands are not threatened by massive international financial speculation, but they are subjected to the discipline such speculation creates, and they are susceptible to devaluation, and even repeated devaluations, as countries seek to protect the value of exports in an increasingly competitive world. The end of the Lomé Agreement, for example-unless it is replaced by something much the samecould well bring another devaluation of the Fiji dollar simply because of its negative impact on Fiji's export earnings. As is known from Fiji's experience in the last year, the pain of devaluation is felt most by those at the bottom of the pile, because the price of imports increases. Devaluation in Fiji assisted the tourist industry at the expense of many ordinary Fiji citizens, whose dollars no longer bought as much as they had before. In the longer term, South Pacific governments may have to abandon their national currencies altogether in favor of a regional currency or even the use of the Australian dollar (in the same way as northern Pacific governments use the American dollar). If that were to happen, governments of the region would lose much of the control they now have over national economic life, and would become branch offices of the Australian Reserve Bank. Currency unions of the European kind are now on the globalization agenda. 


\section{Counterbalancing Globalization}

In a world rapidly headed for the so-called level playing field, the Pacific Islands will continue to argue that they are special and should be treated specially. Development classification, for example, has long been important for Pacific Island countries, because to be classified by international organizations as a Least Developed Country brings benefits and concessions even in a rapidly globalizing world. For this reason the South Pacific Forum pushed again for the completion of a comprehensive vulnerability index-a measure of the exposure of economies to forces beyond government control, such as natural disasters, smallness, and isolation-which could then be included among the criteria for determining Least Developed Country status. Vulnerability is an issue raised by Pacific ACP ministers in their talks over Lomé with the European Union, and it will be raised again at the United Nations special session on small island developing states in 1999 .

The trouble is that the new rules of a globalizing world are being set by people who have little interest in small places or special cases. On the contrary, the whole logic of globalization is to standardize rules so that there are no special breaks for any country, whatever its circumstances. Comparative advantage is everything, and if a country doesn't have many comparative advantages, that's bad luck.

To be fair, all is not gloom. Most Pacific Island societies have characteristics that will counterbalance globalization.

The first is communal land tenure, much derided by aid donors as a barrier to development. For all its faults, communal land tenure continues to act in many countries as an informal system of social security, which is needed now and might be needed more if the Pacific becomes more marginalized in a globalized economy. The second is out-migration to New Zealand, Australia, Canada, and the United States and the return flow of remittances to families in the Pacific. Migration gives the Pacific a direct economic connection to those economies-the advanced ones-that most benefit from globalization and creates a flow of resources in the opposite direction from the normal one. The third is smallness itself, which seems to encourage compromise in politics and, for the most part, stable political systems.

Nevertheless, just as the place of the Pacific Islands in the first globalization was to be subordinate to the temperate, developed world, so their 
place in the second globalization is also to be subordinate, this time to a set of international institutions that have set the rules of the global economy. The new globalization, now combined with independent, sovereign rule, means incorporation into the global economy on terms that suit the interests of the financial markets, the aid donors, and those relatively few Pacific Islanders who are in a position to benefit from the new situation.

This essay was originally delivered on 28 April 1999 at the Oceania Centre for Arts and Culture, University of the South Pacific, as part of a lecture series organized by Epeli Hau'ofa. The essay draws on material previously published in Australia in International Politics: An Introduction to Australian Foreign Policy (Firth 1999).

References

Bairoch, Paul, and Richard Kozul-Wright

1996 Globalization Myths: Some Historical Reflections on Integration, Industrialization and Growth in the World Economy. Discussion Paper II3, March. Geneva: UNCTAD.

Bennett, Judith A

1987 Wealth of the Solomons: A History of a Pacific Archipelago 1800-1978. Pacific Islands Monograph Series 3. Honolulu: University of Hawaici Press.

Dougherty, Michael I966 To Steal a Kingdom. Waimanalo, HI: Island Style Press.

Firth, Stewart

I999 Australia in International Politics: An Introduction to Australian Foreign Policy. Sydney: Allen \& Unwin.

Forum Secretariat

I998 The Lomé Convention and the South Pacific. Suva: Forum Secretariat and University of the South Pacific. Knapman, Bruce

Knapman, Bruce

I985 Capitalism's Economic Impact in Fiji, I874-1939: Development or Underdevelopment? Journal of Pacific History 20 (I-2): 66-83. 